\title{
Pharmacognostical study of Ochrosia elliptica Labill. (Apocynaceae)
}

\author{
Riham A. El-shiekh*, Dalia A. Al-Mahdy, Mohamed S. Hifnawy, Essam A. Abdel-sattar \\ Department of Pharmacognosy, Faculty of Pharmacy, Cairo University, Cairo, 11562, Egypt.
}

\begin{tabular}{l}
\hline ARTICLE INFO \\
\hline Received on: 06/02/2019 \\
Accepted on: 11/04/2019 \\
Available online: 08/05/2019 \\
\hline Key words: \\
Ochrosia elliptica, Botanical \\
study, DNA fingerprinting, \\
RAPD, ISSR: Alkaloids.
\end{tabular}

\begin{tabular}{l}
\hline ABSTRACT \\
Ochrosia elliptica Labill. is a small shrub belonging to family Apocynaceae and well-known as a promising anti- \\
cancer agent. Botanical study of the plant was done for the young and old stems, stem bark, and leaves. Laticiferous \\
tubes with yellowish brown content, isodiametric stone cells (sclereids), sclerenchyma (rod-like), and calcium oxalate \\
clusters are the main diagnostic elements observed in this plant. Furthermore, DNA fingerprinting was done using \\
rapid amplified (RAPD) and inter simple sequence repeat (ISSR) techniques with the identification of a total of 30 \\
RAPD markers and 17 ISSR markers. Carbohydrates, sterols, catechol tannins, flavonoids, and alkaloids were present \\
in all the organs under investigation. This study could be valuable for quality control of the plant.
\end{tabular}

\section{INTRODUCTION}

Family Apocynaceae (Periwinkle or Dogbane Family) is a large family comprising about 424 genera and 1,500 species (Endress and Bruyns, 2000). Most of its species are characterized by the presence of milky sap, typically laticiferous (Endress and Bruyns, 2000; Kamel et al., 2014). The leaves of the family are entire, more or less fleshy, simple, opposite or opposite decussate, sometimes whorled, and exstipulate. The inflorescences are usually a dichasial cyme with bracteoles. The flowers are small, greenishwhite, regular, hermaphrodite, actinomorphic or sometimes zygomorphic, fragrant, and arranged in umbellate cymes. The fruits are commonly a follicle, capsule, or berry, green in color, and turning when ripe to yellow, red, purple, or orange. The seeds are frequently compressed, $1-3$ on each placenta, flat and winged, sometimes having at one end a tuft of hairs (Bailey, 1953; Metcalfe and Chalk, 1950; Rahman and Akter, 2015; Sennblad and Bremer, 2002; Solereder, 1908).

Ochrosia is one of the Apocynaceae genera containing about 36 species native to Australia and the Pacific and Mascarene Island (Jordan, 1965). It is classified in the tribe Vinceae of the subfamily Rauvolfioideae (Endress and Bruyns, 2000; Kisakurek

"Corresponding Author

Riham A. El-shiekh, Department of Pharmacognosy, Faculty of Pharmacy, Cairo University, Giza, Egypt.E-mail: riham.adel@ pharma.cu.edu.eg et al., 1983). Ochrosia species have various uses in medicine as anti-tumor, anti-inflammatory, anti-oxidant, and anti-malarial (Labib et al., 2016; El-shiekh et al., 2017).

Ochrosia ellptica Labill. is cultivated in Egypt as an ornamental plant, the name refers to the elliptical shape of the leaves. Reviewing the current literature resulted in a few data are available on the botanical features and genetic profile of O. elliptica Labill. This work includes botanical characters of different organs of the plant, as well as, genetic profile and phytochemical screening to facilitate the authentication of the plant.

\section{MATERIALS AND METHODS}

\section{Plant material}

The samples of $O$. elliptica Labill were collected at the fruiting stage from Orman Botanic Garden, Giza, Egypt, in March of the years 2012-2014. The plant was authenticated by Dr. Reem Hamdy, Associate Professor of Taxonomy and Flora, Department of Botany, Faculty of Science, Cairo University. A voucher specimen (No. 28.12.2012) was kept at the Herbarium of the Department of Pharmacognosy, Faculty of Pharmacy, Cairo University.

\section{Botanical study}

The pictures of the macro morphological study were taken using SAMSUNG Galaxy Note 5 phone camera (Samsung, USA). The micro morphological study of cross-sections and powdered samples was done using a light microscope image 
analyzer, Leica DMLB, connected to Leica JVC digital 0.5" CCD camera and Leica QWIN software (Wetzlar, Germany) for the bark, young, and old stems and leaves.

\section{Genetic profiling}

The DNA extraction was performed using a DNeasy Plant Mini Kit (QIAGEN). This study was adopted the method described by Williams et al. (1990). The amplifications were done in an automated thermal cycle (Techni 512) and the resulted products were analyzed by gel electrophoresis on $1.5 \%$ agarose gel and stained with ethidium bromide.

The primers were obtained from Operon Technologies Inc., Almeda (California, USA) with the following sequences for rapid amplified (RAPD) analysis; A-01: 5'CAGGCC CTT C 3', A-07: 5' GAA AGG GGT G 3', A-10: 5'GTA GAC CCG T 3', A-18: 5' GTA GAC CCG T 3', B-01: 5' GTT TCG CTC C 3', C-19: 5'GTT GCC AGC C $3^{\prime}$ and HB-09: 5' GTG TGT GTG TGT GC 3', HB-10: 5'GAG AGA GAG AGA CC 3', HB-11: 5' GTG TGT GTG TGT TGT CC 3', HB-13: 5' GAG GAG GAG GC 3', HB-15: 5' CTC CTC CTC GC 3', for inter simple sequence repeat (ISSR) analysis. The Statistical analysis was done using SPSS-10 software.

\section{Phytochemical screening}

The leaves, stems, fruits, and stem bark were separately air-dried, powdered, and then subjected to phytochemical screening by testing the presence or absence of crystalline sublimates, volatile oils, carbohydrate and/or glycosides, tannins, flavonoids, saponins, sterols and/or triterpenes, anthraquinones, and cardiac glycosides (Harborne, 1973; Raman, 2006; Sofowara, 1993; Trease and Evans, 2002; Wagner and Bladt 1996).

\section{RESULTS AND DISCUSSION}

\section{Botanical study}

\section{Macromorphology}

Ochrosia elliptica Labill. (Fig. 1I and II) is a small tree or shrub, cultivated in Egypt. The tree has a pale brown bark and shows clusters of yellow or white flowers appearing from January till July, followed by bright red, poisonous (inedible) fruits borne in pairs, and fully ripening in October. It reaches up to $8 \mathrm{~m}$ in height. All parts of the tree exude a milky sap.

The stem bark:

The stem bark (Fig. 2I and III) is greyish brown in color, hard, rough, showing longitudinal, and transverse wrinkles in the outer surface and longitudinal striations in the inner surface. The bark is bitter in taste, pale yellow, and odorless.

\section{The lateral branch:}

The old branch (Fig. 2III and IV) is pale brown in color, cylindrical in shape, hard, with striated surface. The young stem is green in color, glabrous to naked eye, showing longitudinal fine striations with a fibrous fracture and hollow interior. Branching is monopodial. It has a slightly bitter taste and a faint characteristic odor. It produces a milky white exudate when incised.
The leaf:

The leaves (Figs. 2IV-V and 3) are dark green in color, whorled, and petiolate. The leaf lamina is obovate, oblong, or elliptical in shape with obtuse or rounded apices, entire margin and symmetric decurrent base. It shows pinnate reticulate venation. The upper and lower surfaces are glabrous. The leaf measures $4-12 \mathrm{~cm}$ in length and $1.5-4 \mathrm{~cm}$ in width with a leathery texture. The petiole is very short (Fig. 3I and II), cylindrical, pale green, and glabrous. It measures $0.4-1 \mathrm{~cm}$ in length and $0.1-0.2$ $\mathrm{cm}$ in diameter. The leaf has a bitter taste and a characteristic odor. Petioles produce a milky exudate.

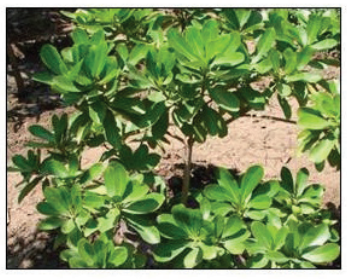

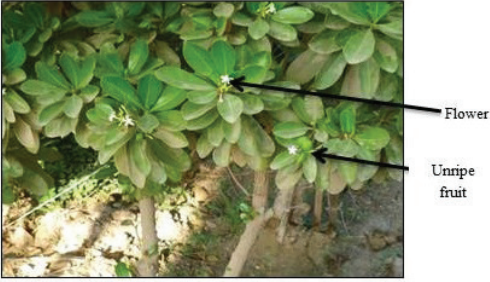

II
Figure 1. Photographs of the entire plant and the shrub (in the fruiting period) of Ochrosia elliptica Labill. (I) The entire plant $(X=0.004)$, (II) The entire flowering plant $(X=0.006)$.

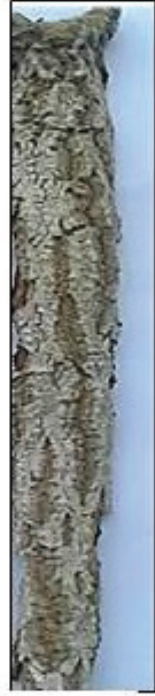

I

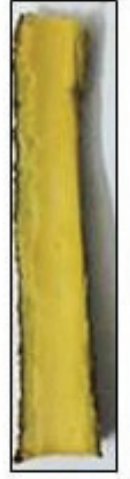

II

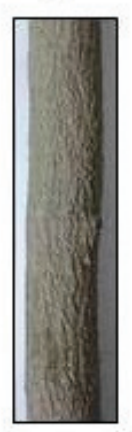

III

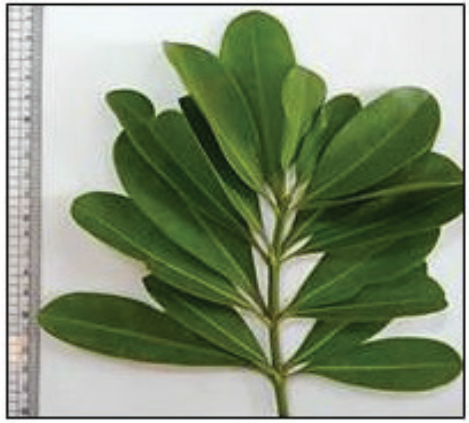

IV

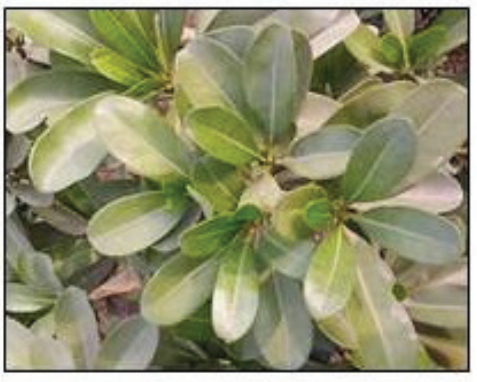

V
Figure 2. Photographs of the stem bark and branches of $O$. elliptica Labill. (I) Outer surface of the stem bark $(X=0.68)$, (II) Inner surface of the stem bark ( $X=0.73$ ), (III) Trunk of the plant showing old branch $(X=0.45)$, (IV) Lateral branch of the plant $(X=0.42),(\mathrm{V})$ A branch showing whorled leaf arrangement $(X=0.73)$ 
The flower:

Flowering starts in January and continues till June. The flowers appear in terminal clusters. They are small, creamy white (Fig. 3III) to yellow (Fig. 3IV) in color, and hermaphrodite.

The fruit:

The fruit is present in pairs turning bright red in color after ripening in August. The fruit is oval, fleshy, has a faint characteristic odor, $5-6 \mathrm{~cm}$ in length and $2-3 \mathrm{~cm}$ in diameter, resembling elongated tomatoes or a pair of red horns, giving rise to its common name, blood-horns. They are one-seeded drupes with thick fibrous endocarp (Fig. 4IV and V) enclosing the seed (Fig. 4V). The fruits are poisonous (inedible) and they copiously exude a sticky latex when incised.

\section{Micromorphology}

The stem:

The old branch (Fig. 5): The transverse section is circular in outline, showing the following:

The cork: It comprises of 6-10 rows of tangentially elongated and radially arranged brown cells with thick suberized walls. The outermost cells shows uneven suberized thickening on the outer tangential and two radial walls (horse-shoe like thickening). The phellogen consists of two to three rows of thin cellulosic walls and tangentially elongated cells.

The cortex: It is formed of 16-24 rows of parenchyma cells with scattered calcium oxalate clusters, starch granules and some cells contain tannin (green color with $\mathrm{FeCl}_{3}$ T.S.). The endodermis is indistinct.

The pericycle: It is composed of parenchyma cells and groups of non-lignified fibers. Scattered calcium oxalate clusters

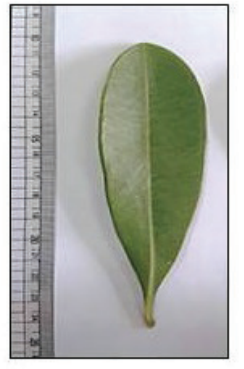

I

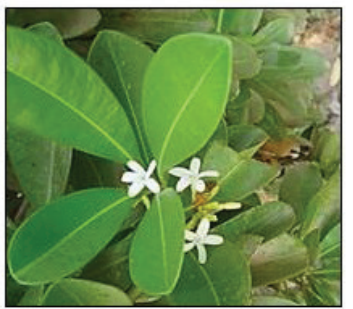

III

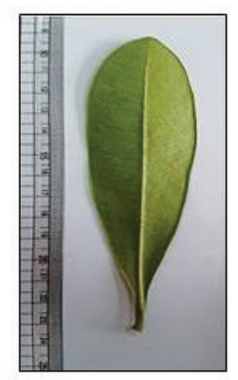

II

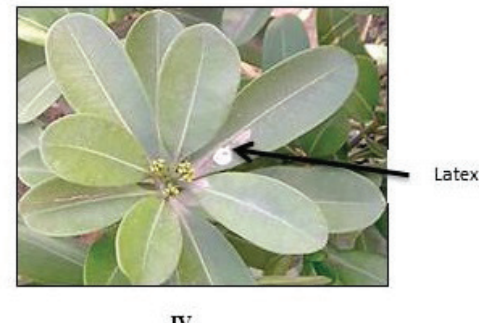

IV
Figure 3. Photographs of the leaf and flower of $O$. elliptica Labill. (I) The upper surface of the leaf $(X=0.52)$, (II) The lower surface of the leaf $(X=0.50)$, (III) A branch showing white flowers $(X=0.46)$, (IV) A branch showing yellow flowers $(X=0.25)$.

are present in parenchyma cells of pericycle. The fibers are spindle shaped having straight or undulating walls, moderately wide lumina and blunt apices as shown in the powder.

The vascular tissue: The vascular bundle is collateral in type, which is surrounded by bundles of intra-xylary phloem at the margin of the pith and traversed by narrow uniseriate medullary rays. The parenchyma cells of phloem are traversed by laticiferous

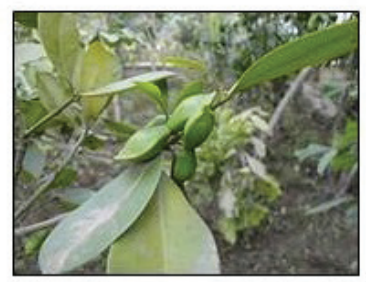

I

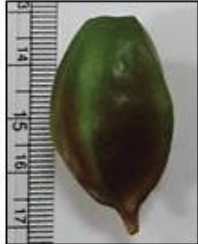

II

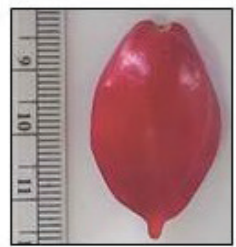

III

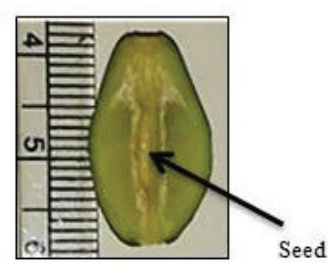

IV

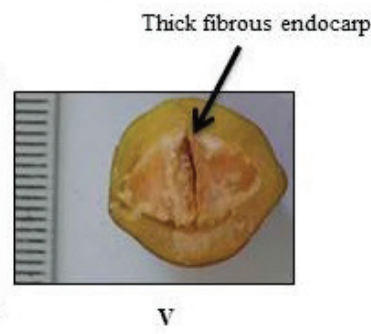

Figure 4. Photographs of the fruit of Ochrosia elliptica Labill. (I) A fruiting branch, (II) Unripe fruit ( $X=0.32$ ). (III) Ripe fruit $(X=0.69)$, (IV) L. cut in the fruit $(X=0.64),(\mathrm{V}) \mathrm{T}$. cut in the fruit $(X=0.89)$.
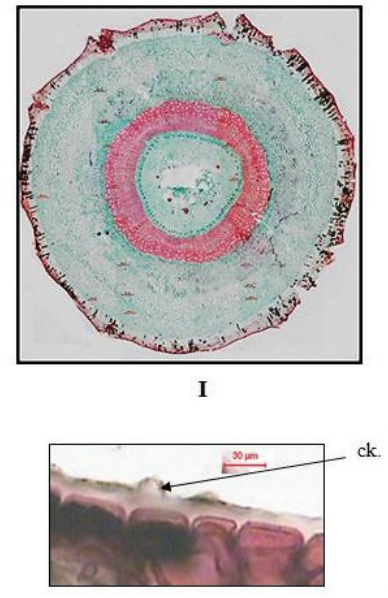

III

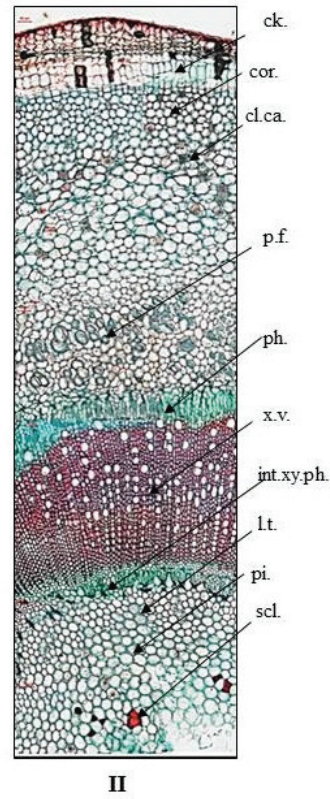

Figure 5. Photographs of transverse sections in old stem of $O$. elliptica Labill. (I) T.S. in the old stem (Low power view) $(X=10)$, (II) T.S. in the old stem (High power view) $(X=80)$, (III) Outermost cells of cork (side view) $(X=400)$. ck.: cork; cl.ca.: clusters of calcium oxalate; cor.: cortex; int.xy.ph.: intra-xylary phloem; 1.t.: laticiferous tubes; p.f.: pericyclic fibers; ph.: phloem; pi.: pith; scl.: sclereids; v.b.: vascular bundle; x.v.: xylem vessels. 
tubes (brown color with iodine T.S.). The xylem vessels are lignified with annular, pitted, or spiral thickenings as shown in the powder. Wood fibers are with straight or tortuous lignified walls, wide lumina, and acute apices as shown in the powder. Wood parenchyma is rectangular with lignified bordered pitted walls as shown in the powder.

The pith: The pith is relatively narrow of parenchymatous cells contain scattered calcium oxalate clusters, starch granules, and showing also isodiametric stone cells or rod-like sclerenchymatous cells having thick lignified walls and narrow lumina. The pith is traversed by laticiferous tubes.

The young branch (Fig. 6): The differences between young and old branches are as the following:

1- The young branch is more or less quadrangular in outline.

2- The epidermis is axially elongated, covered with smooth cuticle, having straight anticlinal walls, and devoid of stomata.

3- The cortical tissue is composed of five to eight rows of thick walled collenchyma cells followed by parenchyma cells.

4- The vascular tissue is very narrow, collateral, widening at the corners, and showing bundles of intra-xylary phleom.

5- The pith is wide, parenchymatous with starch granules and traversed by laticiferous tubes. The stone cells are absent.

Powdered branch (Fig. 7): The powder is bitter in taste, yellowish brown in color, and odorless. It is identified under microscope by the following:

1- Polygonal brown cells of the cork with uneven thickened suberized walls.

2- Polygonal elongated cells of the epidermis with smooth cuticle, having straight anticlinal walls, and devoid of stomata.

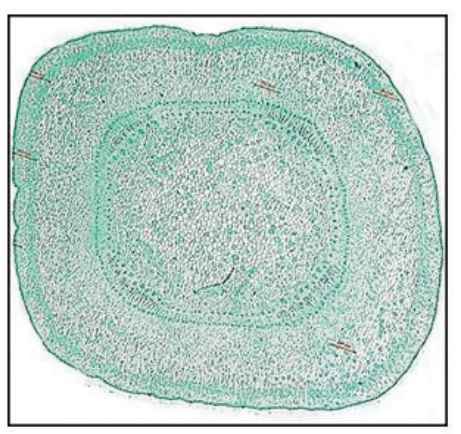

I

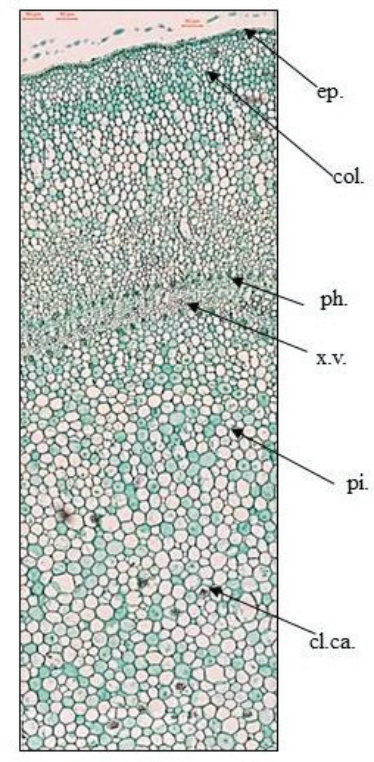

II
Figure 6. Photographs of transverse sections in the stem of $O$. elliptica Labill. (I) T.S. in the young stem (Low power view) $(X=20)$, (II) T.S. in the young stem $(X=80)$ (High power view). cl.ca.: clusters of calcium oxalate; col.: collenchyma; ep.: epidermis; int.xy.ph.: intra-xylary phloem; 1.t.: laticiferous tubes; ph.: phloem; pi.: pith; v.b.: vascular bundle; x.v.: xylem vessels.
3- Thin walled parenchyma cells of the cortex containing calcium oxalate clusters and simple, rounded starch granules.

4- Non-lignified pericyclic fibers.

5- Lignified wood fibers.

6- Wood parenchyma with bordered pitted walls.

7- Rectangular cells of medullary rays with thin walls.

8- Spiral, annular or pitted xylem vessels.

9- Parenchyma cells of the pith with starch granules which are simple and circular in shape.

10-Isodiametric stone cells (sclereids) and sclerenchyma (rodlike).

The microscopical measurements of the old and young branch elements are shown in Table 1.

The stem bark: following:

The cross-section of the stem bark (Fig. 8) displays the

The cork: It is wide and formed of 13-18 rows of tabular brown cells with thick suberized walls. The outermost cells shows uneven suberized thickening on the outer tangential and two radial walls (horse-shoe like thickening).

The cortex: The cortex is parenchymatous traversed by yellowish brown laticiferous tubes. The cells contain starch granules, calcium oxalate prisms, clusters, and tannins.

The pericycle: The pericycle is parenchymatous with scattered non-lignified fibers. The fibers are spindle shaped having straight or undulating, thin non-lignified walls with moderately wide to narrow lumina and tapering apices. The parenchyma cells contain scattered calcium oxalate clusters.

The phloem: The tissue of phloem consists of parenchyma cells, sieve tubes, companion cells, lignified scattered isodiametric sclereids, and elongated fiber-like sclerenchyma having lignified pitted walls and wide or narrow lumina. It is

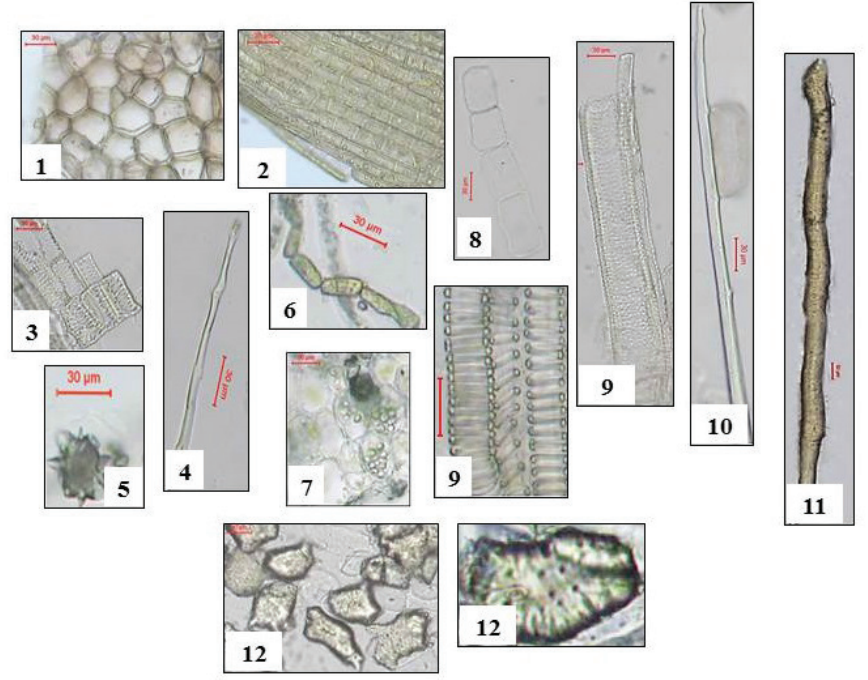

Figure 7. Photographs of different elements in powdered Ochrosia elliptica Labill. stem. 1: cork cells $(X=333.33), 2$ : epidermal cells $(X=333.33)$, 3: wood parenchyma $(X=200), 4$ : wood fibers $(X=300), \mathbf{5}$ : clusters of calcium oxalate $(X=366.66), 6$ : laticiferous tubes $(X=333.33), 7$ : starch granules $(X=166.6)$, 8: medullary rays $(X=200), 9$ : xylem vessels $(X=166.60)$, 10: pericyclic fibers $(X=233.33), 11$ : sclerenchyma $(X=80), \mathbf{1 2}$ : sclereids $(X=133.33)$. 
Table 1. Microscopical measurements of the different elements of Ochrosia elliptica L. organs (in microns).

\begin{tabular}{|c|c|c|c|c|}
\hline Elements & Length & Width & Height & Diameter \\
\hline \multicolumn{5}{|c|}{ The stem } \\
\hline Calcium oxalate clusters & & & & $18-\underline{22}-30$ \\
\hline Cork cells & $14-\underline{30}-50$ & $13-\underline{23}-37$ & $17-\underline{29}-50$ & \\
\hline Epidermal cells & $14-\underline{20}-30$ & $11-\underline{13}-30$ & $10-\underline{17}-30$ & $7-\underline{10}-12$ \\
\hline Laticiferous tubes & $250-\underline{300}-350$ & & & $5-\underline{7}-15$ \\
\hline Medullary rays & $40-\underline{45}-55$ & $25-\underline{30}-35$ & & \\
\hline Pericyclic fibers & $450-\underline{600}-700$ & $3-\underline{5}-6$ & & \\
\hline Sclereids & $50-\underline{60}-70$ & $25-\underline{38}-50$ & & \\
\hline Sclerenchyma & $800-\underline{1,000}-1,100$ & $10-\underline{12}-20$ & & \\
\hline Starch granules & & & & $4-\underline{6}-8$ \\
\hline Wood parenchyma & & & & $30-\underline{32}-40$ \\
\hline Wood fibers & $350-\underline{400}-450$ & $6-\underline{10}-15$ & & \\
\hline Xylem vessels & & & & $28-\underline{30}-40$ \\
\hline \multicolumn{5}{|c|}{ Stem bark } \\
\hline Calcium oxalate clusters & & & & $11-\underline{19}-23$ \\
\hline Calcium oxalate prisms & $30-\underline{32}-40$ & $10-\underline{18}-20$ & & \\
\hline Cork cells & $25-\underline{33}-50$ & $8-\underline{25}-41$ & $12-\underline{33}-50$ & \\
\hline Laticiferous tubes & $500-\underline{654}-800$ & & & $30-\underline{38}-45$ \\
\hline Medullary rays & $50-\underline{65}-80$ & $35-\underline{43}-50$ & & \\
\hline Pericyclic fibers & $800-\underline{1,152}-1,500$ & $7-\underline{14}-24$ & & \\
\hline Sclereids & $30-\underline{50}-70$ & $35-\underline{50}-65$ & & \\
\hline Sclerenchyma & $850-\underline{903}-950$ & $12-\underline{17}-22$ & & \\
\hline \multicolumn{5}{|c|}{ Leaf } \\
\hline Calcium oxalate clusters & & & & $25-\underline{30}-40$ \\
\hline Hypodermis & & & $33-\underline{45}-50$ & \\
\hline Laticiferous tubes & $600-\underline{850}-1113$ & & & $10-\underline{13}-20$ \\
\hline Lower epidermis & $15-\underline{30}-50$ & $10-\underline{14}-30$ & $14-\underline{17}-20$ & \\
\hline Lower neural epidermis & $19-\underline{40}-56$ & $11-\underline{13}-19$ & $14-\underline{17}-20$ & \\
\hline Medullary rays & $60-\underline{75}-90$ & $60-\underline{70}-80$ & & \\
\hline Palisade cells & $50-\underline{60}-70$ & $10-\underline{12}-15$ & & \\
\hline Petiole epidermal cells & $14-\underline{23}-32$ & $6-\underline{16}-30$ & $6-\underline{7}-10$ & \\
\hline Starch granules & & & & $5-\underline{7}-10$ \\
\hline Stomata & $12-\underline{18}-24$ & 6-9-12 & & \\
\hline Tracheids & $150-\underline{176}-200$ & $4-\underline{9}-13$ & & \\
\hline Upper epidermis & $15-\underline{30}-45$ & $18-\underline{21}-24$ & $14-\underline{17}-20$ & \\
\hline Upper neural epidermis & $26-\underline{51}-75$ & $11-\underline{15}-19$ & $14-\underline{17}-20$ & \\
\hline Wood fibers & $900-\underline{950}-1,000$ & $10-\underline{13}-15$ & & \\
\hline Wood parenchyma & $183-\underline{235}-283$ & $83-\underline{100}-117$ & & \\
\hline Xylem vessels & & & & $28-\underline{30}-32$ \\
\hline
\end{tabular}

The underlined values represent the common measurement of each element.

traversed by bi- to tri-seriate medullary rays and laticiferous tubes. Phloem parenchyma cells contain starch granules and calcium oxalate prisms. Phloem fibers are absent. The parenchyma cells of the cortex, pericycle, and phloem contain starch granules.

Powdered stem bark (Fig. 9): The powder is odorless, brown in color with a bitter taste. It is identified by:

1- Polygonal brown cells of cork with thick suberized walls having uneven thickening.
2- Parenchyma cells of the cortex contain calcium oxalate prisms and clusters.

3- Non-lignified fibers of pericycle.

4- Isodiametric sclereids and elongated fiber-like sclerenchyma.

5- Polygonal elongated thin walled cells of medullary rays.

6- Elongated thin walled laticiferous tubes with yellowish brown content.

The microscopical measurements of the stem bark elements are shown in Table 1. 
The leaf:

The leaf lamina (Fig. 10): The transverse section displays upper and lower epidermises, surrounding a dorsiventral mesophyll.

The epidermis: The upper epidermis consists of polygonal isodiametric cells without stomata, covered with smooth cuticle and having straight anticlinal walls as shown in the surface

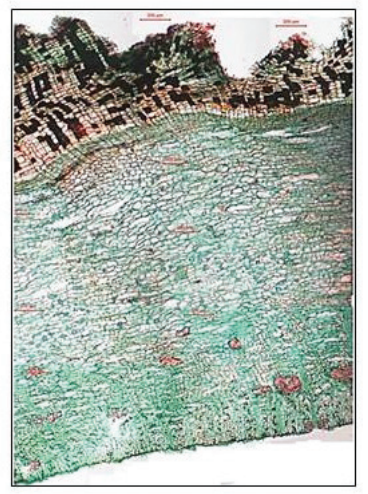

I

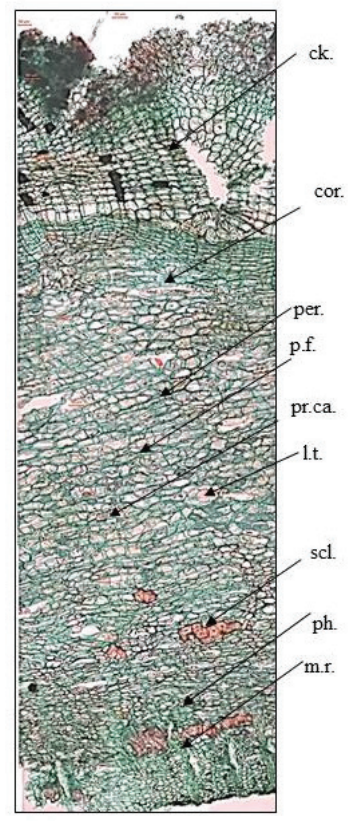

II

Figure 8. Photographs of transverse section in bark of $O$. elliptica Labill. (I) T.S. in the bark (Low power view) $(X=25)$, (II) T.S. in the bark (High power view) $(X=80)$. ck.: cork; cor.: cortex; 1.t.: laticiferous tubes; m.r.: medullary rays; per.: pericycle; p.f.: pericyclic fibers; ph.: phloem; pr.ca.: prisms of calcium oxalate; scl.: sclereids.

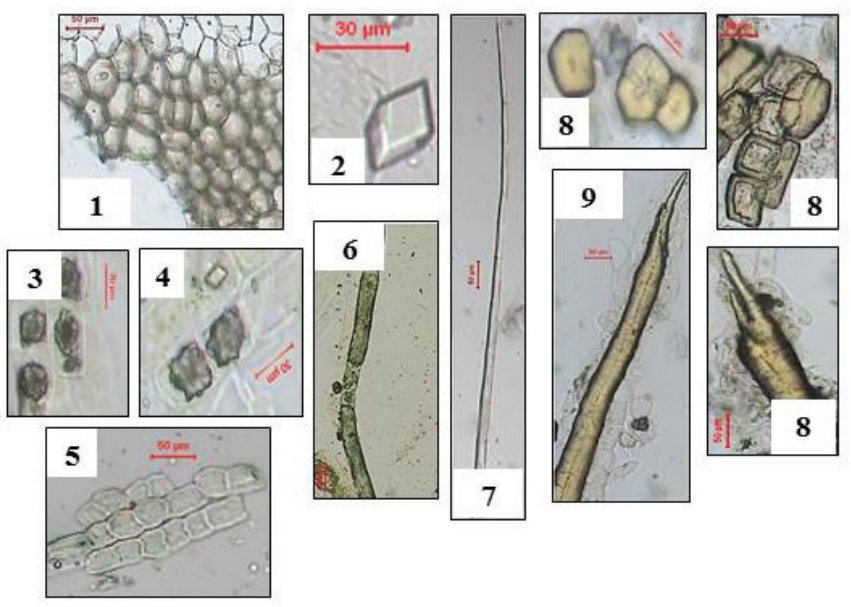

Figure 9. Photographs of different elements in powdered $O$. elliptica Labill. bark. 1: cork cells $(X=180), 2$ : prisms of calcium oxalate $(X=366.66), 3$ : clusters of calcium oxalate $(X=266.6), 4$ : cortex $(X=266.6), 5$ : medullary rays $(X=140), 6$ : laticiferous tubes $(X=133.3), 7$ : pericyclic fibres $(X=140), \mathbf{8}$ : sclereids $(X=100,120,216.6), 9$ : sclerenchyma $(X=80)$.

view. The lower epidermis consists of elongated cells with smooth cuticle and straight anticlinal walls. Stomata are mostly anisocytic with few anomocytic stomata as shown in the surface view. The guard cells are kidney shaped, slightly raised above the epidermal cells. The epidermis is followed by one row of hypodermis, showing straight anticlinal walls of polygonal isodiametric cells.

The neural epidermis: The upper and lower neural surfaces consists of polygonal axially elongated cells, covered with smooth cuticle, having straight thin walls, and devoid of stomata.

The mesophyll: The palisade is formed of two rows of columnar cells with straight anticlinal walls and containing green plastids. The palisade is interrupted in the midrib region with collenchymatous cells. The spongy tissue is formed of irregularly shaped parenchyma cells with scattered calcium oxalate clusters.

The midrib: The upper cortical tissue in the midrib region is collenchymatous cells (four to eight rows) followed by parenchymatous cells (six to eight rows), while the lower cortical tissue is formed of four to six rows of collenchyma cells below $8-10$ rows of parenchymatous cells with scattered calcium oxalate clusters and tannins.

The pericycle: The pericycle is formed of rounded parenchyma cells with scattered calcium oxalate clusters.

The vascular tissue: The vascular bundle is one crescent shaped bicollateral bundle, traversed by polygonal or slightly elongated cells of uni- to bi-seriate medullary rays. The xylem shows spiral or annular lignified thickenings. Wood parenchyma is rectangular in shape having thin lignified walls. The cambium is formed of two to three rows of tangentially elongated cambiform cells. Tracheids are pitted, elongated with thin lignified walls and blunt ends. The phloem is formed of phloem parenchyma containing starch granules, soft sieve elements, and laticiferous tubes.
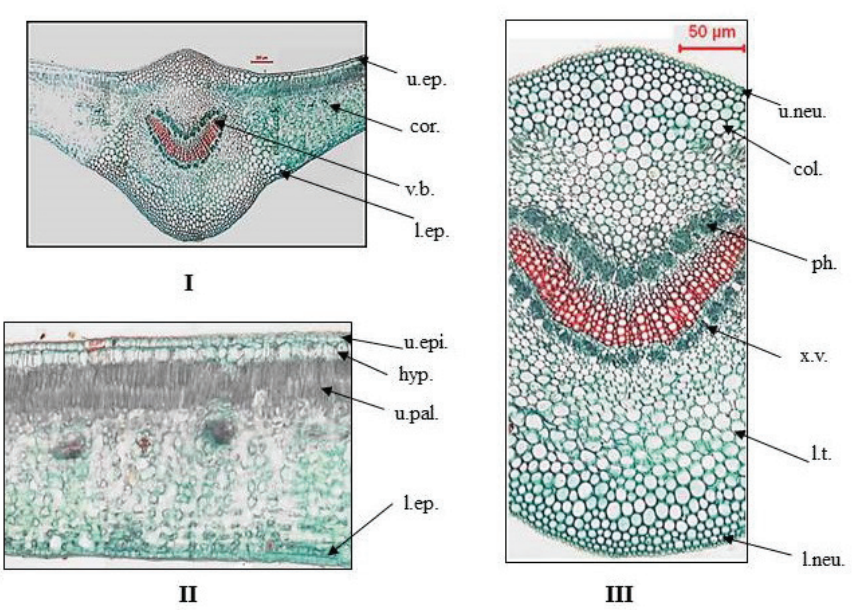

III

Figure 10. Photographs of transverse section in leaf of $O$. elliptica Labill. (I) T.S. in the leaf (Low power view) $(X=25)$, (II) T.S. in the lamina (High power view) $(X=260)$, (III) T.S. in the midrib (High power view) $(X=60)$. col.: collenchyma; cor.: cortex; hyp.: hypodermis; 1.ep.: lower epidermis; 1.neu.: lower neural epidermis; 1.t.: laticiferous tubes; ph.: phloem; u.ep.: upper epidermis; u.neu.: upper neural epidermis; u.pal.: upper palisade; v.b.: vascular bundle; x.v.: xylem vessels. 
The leaf petiole (Fig. 11): The transverse section is nearly three sided in shape, showing the following:

The epidermis: It is formed of axially elongated polygonal cells, covered with smooth cuticle, having straight thick anticlinal walls, and devoid of stomata.

The cortex: It is collenchymatous (about six rows) followed by $8-10$ rows of parenchymatous cells contain calcium oxalate clusters and prisms and showing two to four small scattered vascular bundles.

The pericycle: It is parenchymatous cells with calcium oxalate clusters.

The vascular tissue: It shows one large arc-shaped, collateral vascular bundle with groups of intra-xylary phleom. They are traversed by polygonal slightly elongated and thin walled cells of uni- to bi-seriate medullary rays. The vascular tissue is formed of tracheids, wood parenchyma, xylem vessels, and wood fibers. The xylem vessels are lignified with spiral or annular thickenings. Tracheids are pitted, elongated with thin lignified walls and blunt ends. Wood parenchyma has thin lignified walls of rectangular cells. Wood fibers have wide lumina, straight or slightly undulating thin lignified walls, and acute apices. The phloem shows phloem parenchyma, sieve elements, and laticiferous tubes. The microscopical measurements of the leaf elements are represented in Table 1.

Powdered leaf (Fig. 12): The powder is odorless, green in color, and bitter in taste. It is identified by the following elements:

1- Polygonal isodiametric cells of upper epidermis with thin, straight anticlinal walls, smooth cuticle without stomata.

2- Polygonal elongated cells of lower epidermis with smooth cuticle, straight anticlinal walls, showing anisocytic and few anomocytic stomata (Fig. 12-2).

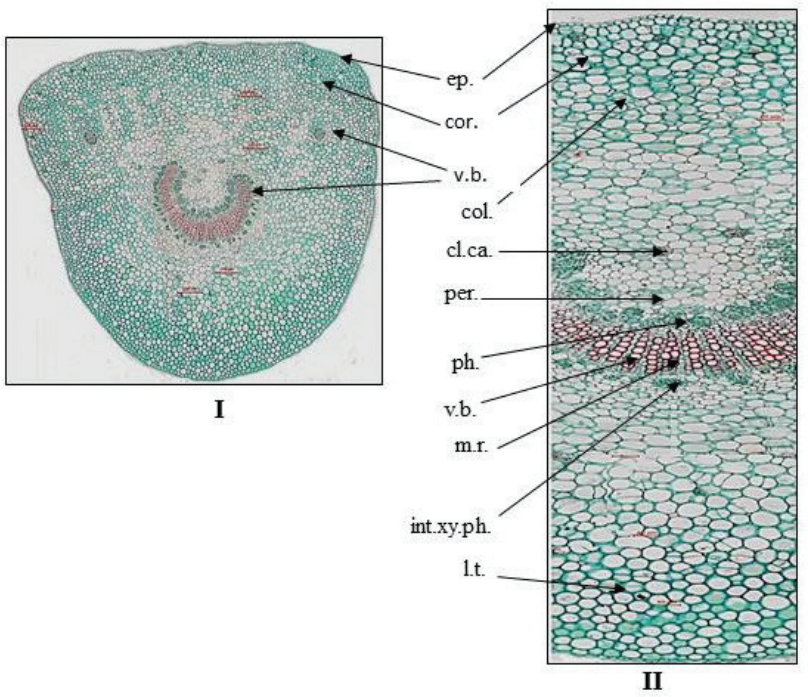

Figure 11. Photographs of transverse section in petiole of $O$. elliptica Labill. (I) T.S. in the petiole (Low power view) $(X=20)$, (II) T.S. in the petiole (High power view) $(X=80)$. cl.ca.: clusters of calcium oxalate; col.: collenchyma; cor.: cortex; ep.: epidermis; int.xy.ph.: intra-xylary phloem; 1.t.: laticiferous tubes; m.r.: medullary rays; per.: pericycle; ph.: phloem; v.b.: vascular bundle; x.v.: xylem vessels.
3- The upper and lower neural epidermal cells.

4- Polygonal isodiametric to elongated cells of the petiole epidermis, covered with smooth cuticle and having thick straight anticlinal walls.

5- Parenchyma cells with calcium oxalate clusters and simple, rounded starch granules of the petiole cortex.

6- Palisade cells containing green plastids.

7- Parenchyma cells of the leaf cortex showing starch granules which are simple and circular in shape (blue color with iodine T.S).

8- Scattered calcium oxalate clusters.

9- Spiral and annular xylem vessels.

10-Lignified fibers of wood, having straight walls, wide lumina, tapering apices and fusiform in shape.

11-Pitted, elongated tracheids with thin lignified walls and blunt ends.
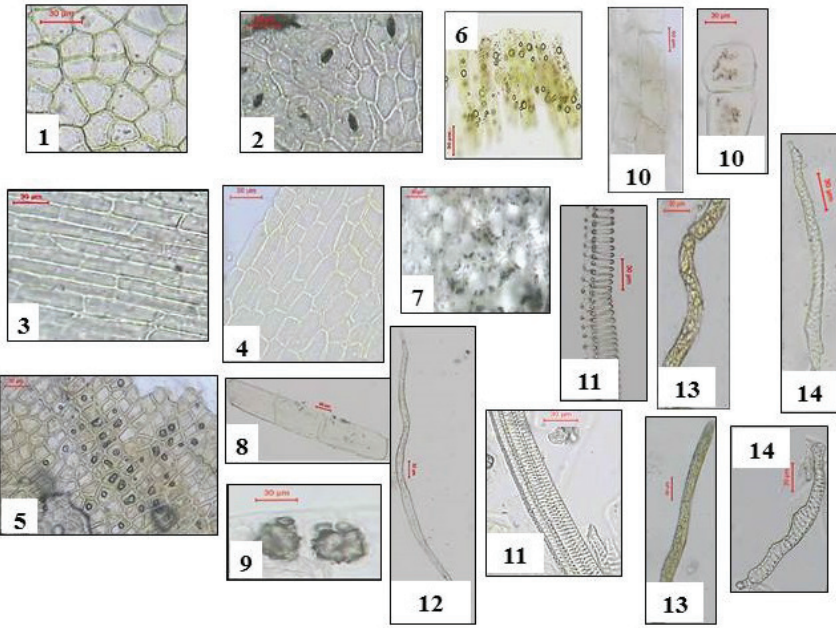

Figure 12. Photographs of different elements in powdered $O$. elliptica Labill. leaves. 1: upper epidermis $(X=300), 2$ : lower epidermis $(X=300), \mathbf{3}$ : upper neural epidermis $(X=200), 4$ : lower neural epidermis $(X=200), \mathbf{5}$ : petiole epidermis $(X=166.66)$, 6: upper palisade $(X=200)$, 7: starch granules $(X=133.33), 8$ : wood parenchyma $(X=50)$, 9: clusters of calcium oxalate $(X=200), 10$ : medullary rays $(X=80,266.66), 11$ : xylem vessels $(X=180,200)$, 12: wood fibers $(X=60), 13$ : laticiferous tubes $(X=120,180), 14$ : trachieds $(X=233.33,366.66)$.

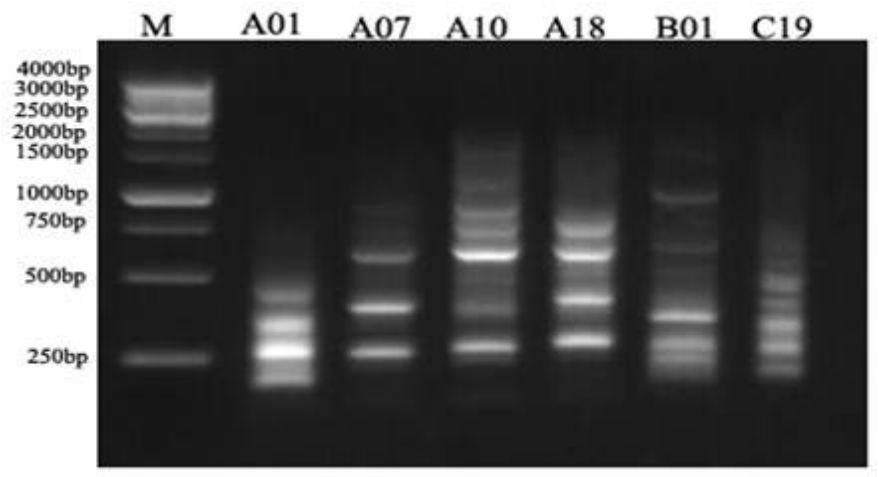

Figure 13. RAPD electrophoretic profile of the $O$. elliptica L. DNA amplified with 6 decamer primers. 
Table 2. Molecular size in base pairs of amplified DNA fragments produced by six decamer primers in Ochrosia elliptica L.

\begin{tabular}{cccccccc}
\hline \multirow{2}{*}{ Band No. } & M.W bp & \multicolumn{7}{c}{ Primer Name } \\
\cline { 2 - 7 } & & A01 & A07 & A10 & A18 & B01 & C19 \\
\hline 1 & 1,255 & 0 & 0 & 1 & 0 & 0 & 0 \\
2 & 1,145 & 0 & 0 & 0 & 0 & 1 & 0 \\
3 & 805 & 0 & 0 & 1 & 1 & 0 & 0 \\
4 & 585 & 0 & 1 & 1 & 1 & 1 & 1 \\
5 & 440 & 1 & 1 & 1 & 1 & 1 & 1 \\
6 & 370 & 1 & 1 & 1 & 1 & 1 & 1 \\
7 & 250 & 1 & 1 & 1 & 1 & 1 & 1 \\
8 & 200 & 0 & 0 & 0 & 0 & 1 & 1 \\
9 & 185 & 1 & 0 & 0 & 0 & 0 & 0 \\
Total & & 4 & 4 & 6 & 5 & 6 & 5 \\
\hline
\end{tabular}

$(1)=$ presence of bands; $(0)=$ absence of bands.

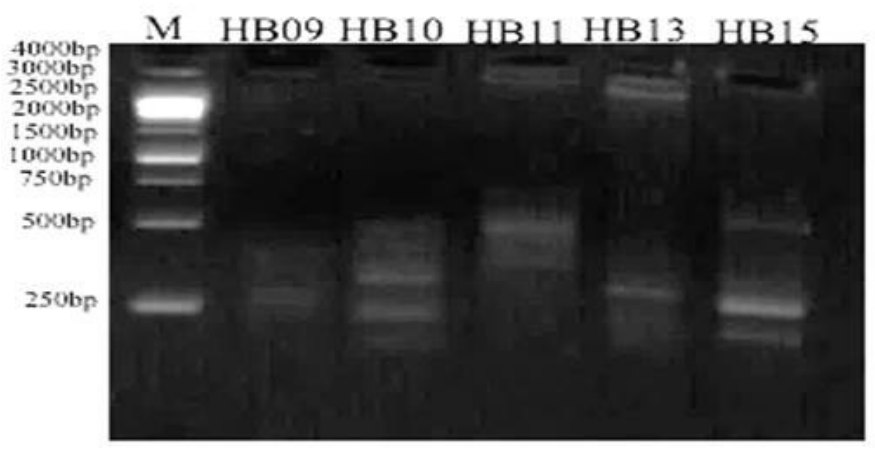

Figure 14. ISSR electrophoretic profile of the O. elliptica L. DNA amplified with the 5 decamer primers.

Table 3. Molecular size in base pairs of amplified DNA fragments produced by five decamer primers in Ochrosia elliptica L.

\begin{tabular}{ccccccc}
\hline \multirow{2}{*}{$\begin{array}{c}\text { Band } \\
\text { no. }\end{array}$} & M.W bp & \multicolumn{5}{c}{ Primer name } \\
\cline { 3 - 7 } & & HB-9 & HB-10 & HB-11 & HB-13 & HB-15 \\
\hline 1 & 3,340 & 1 & 1 & 1 & 1 & 1 \\
2 & 2,480 & 0 & 0 & 0 & 1 & 0 \\
3 & 545 & 0 & 0 & 0 & 1 & 1 \\
4 & 530 & 0 & 0 & 1 & 0 & 0 \\
5 & 365 & 1 & 0 & 0 & 0 & 0 \\
6 & 350 & 0 & 0 & 1 & 0 & 0 \\
7 & 280 & 0 & 0 & 0 & 0 & 0 \\
8 & 215 & 1 & 1 & 0 & 1 & 1 \\
9 & 175 & 0 & 0 & 0 & 1 & 1 \\
Total & & 3 & 2 & 3 & 5 & 4 \\
\hline
\end{tabular}

$(1)=$ presence of bands; $(0)=$ absence of bands.

12-Rectangular cells of wood parenchyma with thin lignified walls.

13-Polygonal, isodiametric thin walled cells of the medullary rays.

14-Elongated thin walled laticiferous tubes with yellowish brown content.
Table 4. Results of preliminary phytochemical screening of the different organs of Ochrosia elliptica L.

\begin{tabular}{lcccc}
\hline Test & Leaves & Stem & Fruit & Stem bark \\
\hline Crystalline sublimate & - & - & - & - \\
Carbohydrate and/or glycosides: & + & + & + & + \\
Tannins: 1-Condensed (catechol) & ++ & + & + & ++ \\
2-Hydrolysable & - & - & - & - \\
Flavonoids: 1-Free & ++ & ++ & + & ++ \\
2-Combined & ++ & ++ & + & ++ \\
Saponins: & - & - & + & + \\
Sterols and/or Triterpenes: & ++ & ++ & + & + \\
Alkaloids: & ++ & + & + & ++ \\
Anthraquinones: & - & - & + & + \\
Cardiac glycosides: & - & - & - & - \\
\hline
\end{tabular}

$(++)$ present in a large amount; $(+)$ present; $(-)$ absent.

\section{Genetic profiling}

The electrophoretic profile of the DNA sample using RAPD generated 30 distinct bands by six decamer primers (Fig. 13; Table 2), where the ISSR profile generated 17 fragment patterns by five decamer primers (Fig. 14; Table 3). The RAPD analysis can select the usage of OPA (Operon Primers A-series)-10, OPB (Operon Primers B-series)-01 and OPC (Operon Primers C-series)-19 primers and the analysis of ISSR can choice the usage of HB-13 and HB-15 primers, for the selective discrimination of $O$. elliptica L. By comparing the two PCR-dependant techniques, it shows that primers of RAPD method can be more informative and useful for the genetic profile of this plant.

\section{Phytochemical screening}

The obtained results were recorded in Table 4. Carbohydrates and/or glycosides, sterols and/or triterpenes, catechol tannins, free and combined flavonoids and alkaloids were present in all organs under investigation, whereas volatile oils, saponins, anthraquinones, and cardiac glycosides were absent in all organs under investigation. These results agreed with the 
previous published data on other Ochrosia species by Elya et al. (2012) and Hafid et al. (2014).

\section{CONCLUSION}

The macro-and micro-morphological characters of the plant, as well as, the DNA fingerprinting could be used for its identification and discrimination. The phytochemical screening revealed the presence of carbohydrates, sterols, triterpenes, catechol tannins, free and combined flavonoids, and alkaloids in all organs under investigation.

\section{FINANCIAL SUPPORT AND SPONSORSHIP} Nil.

\section{CONFLICT OF INTERESTS}

There are no conflicts of interest.

\section{REFERENCES}

Bailey L. The standard cyclopedia of horticulture. The Macmillan Company, New York, NY, p. 311, 1953.

El-shiekh RA, Al-Mahdy DA, Hifnawy MS, Tzanova [T, EvainBana E, Philippot S, Bagrel D, Abdelsattar EA. Themical and biological investigation of Ochrosia elliptica Labill. Cultivated in Egypt. Rec Nat Prod, 2017; 11(6):552-7.

Elya B, Basah K, Mun A, Yuliastuti W, Bangun A, Septiana EK, Cortex CL. Screening of $\alpha$-glucosidase inhibitory activity from some plants of Apocynaceae, Clusiaceae, Euphorbiaceae, and Rubiaceae. J Biomed Biotechnol, 2012; 2012:1-6.

Endress M, Bruyns P. A revised classification of the Apocynaceae. Bot Rev, 2000; 66(1):1-56.

Hafid AF, Ismail, Wardiyanto S, Tumewu L, Rahman A, Widyawaruyanti A. Free-radical scavenging activity screening of some Indonesian plants. Int J Pharm Pharm Sci, 2014; 6:9-11.

Harborne JB. Phytochemical methods. Chapman and Hall Ltd., London, UK, pp. 49-188, 1973.

Jordan WHG. The alkaloids of Ochrosia sandwicensis A. Gray. $\mathrm{PhD}$ Thesis, University of Hawaii, Hawaii, 1965.

Kamel EA, Sharawy SM, Karakish EAK. Cytotaxonomical investigations of the tribes asclepiadeae and ceropegieae of the subfamily asclepiadoideae-apocynaceae. Pak J Bot, 2014; 46(4):1351-61.
Kisakurek MV, Leeuwenberg A, Hesse M. A chemotaxonomic investigation of the plant families of Apocynaceae, Loganiaceae and Rubiaceae by their Indole alkaloid content. Hobsons, London, UK, Vol. 1, pp. 211-376, 1983

Labib RM, Ebada SS, Youssef FS, Ashour ML, Ross SA. Ursolic acid, a natural pentacylcic triterpene from Ochrosia elliptica and its role in the management of certain neglected tropical diseases. Pharmacogn Mag, 2016; 12(48):319-25.

Metcalfe CR, Chalk L. Anatomy of the dicotyledons. The Clarendon Press, Oxford, UK, pp. 905-25, 1950

Rahman AHM, Akter M. Taxonomy and traditional medicinal uses of Apocynaceae (Dogbane) family of Rajshahi District, Banglades. J Bot Sci, 2015; 4(3):1-12.

Raman N. Phytochemical Techniques, New Indian Publishing Agencies, Pitampura, New Delhi. pp. 19, 2006.

Sennblad B, Bremer B. Classification of Apocynaceae s.1. according to a new approach combining Linnaean and Phylgenetic taxonomy. Syst Biol, 2002; 51(3):389-409.

Sofowara A. Medicinal plants and traditional medicine in Africa. Spectrum Books Ltd, Ibadan, Nigeria, pp. 191-289, 1993.

Solereder H. Systematic anatomy of the Dicotyledons. The Clarendon Press, Oxford, UK, pp. 529-37 \& 983-8, 1908.

Trease GE, Evans WC. Pharmacognosy. 15th edition, Bailliere Tindall, Edinburgh; London, pp. 45-50, 2002.

Wagner H, Bladt S. Drug analysis. Springer, New York, NY, p. $335,1996$.

Williams JK, Kubelisk AR, Livak KJ, Rafalski JA, Tingey SV DNA polymorphisms amplified by arbitrary primers are useful as genetic markers. Nucl Acids Res, 1990; 18:6531-5.

\section{How to cite this article:}

El-shiekh RA, Al-Mahdy DA, Hifnawy MS, Abdel-sattar EA. Pharmacognostical study of Ochrosia elliptica Labill. (Apocynaceae). J Appl Pharm Sci, 2019; 9(05):049-057. 